\author{
dr hab. Ewa KROK \\ Wydział Nauk Ekonomicznych i Zarządzania, Uniwersytet Szczeciński \\ e-mail: ewakrok@wp.pl
}

DOI: $10.15290 /$ ose.2016.03.81.08

\title{
WPEYW DOCHODÓW I PRACY NA POZIOM ZADOWOLENIA Z ŻYCIA
}

\begin{abstract}
Streszczenie
Artykuł porusza zagadnienia zadowolenia i satysfakcji z życia, które coraz częściej pojawiają się w kręgu zainteresowań ekonomistów i polityków. Wartości te są kształtowane przez różnorodne czynniki, w tym ekonomiczne. Dokonano analizy i porównań wyników badań empirycznych skoncentrowanych na uchwyceniu wpływu dochodów oraz pracy na zadowolenie z życia.
\end{abstract}

Słowa kluczowe: ekonomia szczęścia, zadowolenie, poziom satysfakcji z życia, dochody, bezrobocie

\section{IMPACT OF INCOME AND WORK ON SUBJECTIVE WELL-BEING}

\section{Summary}

The article concentrates on happiness and life satisfaction, which are increasingly of economists and politicians interest. These values are shaped by a variety of factors, including economics. The author analyzed and compared the results of empirical research focused on capturing the impact of income and jobs for well-being.

Key words: economics of happiness, well-being, life satisfaction, income, unemployment

JEL: I31, A13

\section{Wstęp}

Badaniem poziomu zadowolenia z życia i czynników go determinujących zajmują się już nie tyko filozofowie, psychologowie i socjologowie, ale także ekonomiści i politycy. Satysfakcja z życia nie jest rozpatrywana jedynie w ujęciu indywidualnym, lecz coraz częściej staje się elementem polityki społecznej i ma swój udział w stanowieniu prawa. Ekonomiści badają relacje między poziomem zadowolenia a dochodami, zatrudnieniem i poziomem inflacji, z kolei, politycy zastanawiaja się, czy głównym wyznacznikiem działań rządu powinna być maksymalizacja poziomu szczęścia w społeczeństwie. 
Na podstawie przeglądu literatury i zestawienia wyników badań empirycznych w artykule dokonano analizy wpływu na poziom zadowolenia dwóch wybranych czynników ekonomicznych, tj.: dochodów i bezrobocia.

\section{Zadowolenie z życia i metody jego pomiaru}

W wielu pozycjach literaturowych [Tatarkiewicz, 2003, s. 15-29; Bruni, Porta, 2007, s. 17; Carr, 2009, s. 21; Linley, Joseph, 2007, s. 20; Ahuvia, Friedman, 1998, s. 153-168; Diener, Seligman, 2004, s. 1-31; Kahneman, 2012, s. 84-88] poczucie całościowego zadowolenia z dotychczasowego życia jest utożsamiane ze szczęściem. Choć jednocześnie autorzy są ci zgodni co do faktu, iż pojęcie szczęścia jest bardzo niejednoznaczne i trudno definiowalne. Wskazują oni na istotne rozróżnienie między bieżącym doświadczaniem satysfakcji (emocjami) a postrzeganiem życia jako szczęśliwego (uczuciem). Zauważaja iż całościowe zadowolenie z życia zazwyczaj nie jest trafną miara aktualnego samopoczucia i odwrotnie: doznawana właśnie satysfakcja nie przesądza o długookresowym uczuciu szczęścia. Jednakże z badań przeprowadzonych wśród mieszkańców Unii Europejskiej [Eurostat, 2015] wynika, że im częściej człowiek doznaje spełnienia, tym większe jest prawdopodobieństwo, że wysoko oceni całościowe zadowolenie z życia.

Odczuwanie szczęścia jest bardzo ważnym elementem życia człowieka, stąd jest prowadzonych wiele badań, których celem jest ustalenie wpływu różnorodnych czynników na zadowolenie z życia, jego jakość i dobrostan. W praktyce do ustalania poziomu szczęścia są stosowane następujące metody:

- kompleksowa samoocena indywidualnego zadowolenia z życia, na podstawie reprezentatywnych badań ankietowych;

- $\quad$ metoda wyrywkowej kontroli doznań (Experience Sampling Method - ESM), nazywana też metoda pobierania próbek doświadczenia. Osoby badane są wyposażone w elektroniczne pagery i co jakiś czas, gdy zabrzmi sygnał, maja zarejestrować to, co w danym momencie czują i myśla;

- metoda rekonstrukcji dnia (Day Reconstruction Method - DRM), w której osoby badane są proszone o w miarę szczegółowe przypomnienie sobie wydarzeń dnia poprzedniego i zdefiniowanie uczuć, jakie im towarzyszyły w związku z tymi wydarzeniami;

- $\quad$ metoda zwana obrazowaniem mózgu (Brain Imaging - BI), wykorzystująca rezonans magnetyczny do badania reakcji mózgu na pozytywne i negatywne emocje [Diener i in. 1999; Kahneman i in. 1999; Kahneman, Krueger, 2006].

W badaniach empirycznych najczęściej jest stosowana pierwsza metoda, która rejestruje deklaratywną ocenę satysfakcji z życia. Przeważanie wykorzystuje się tzw. skalę drabinowa gdzie respondent odpowiada na pytanie: „Jakie masz poczucie: na którym szczeblu drabiny aktualnie się znajdujesz?”, gdzie 0 oznacza „Życie, które uznałbyś dla siebie za najgorsze z możliwych”, a 10 oznacza „Życie, które uznałbyś dla siebie za najlepsze z możliwych". Pozostałe trzy metody badaja poziom odczuwanego dobrego samopoczucia w określonych momentach i sytuacjach życia. Zbierane dane pozwalają prowadzić analizy porównawcze szczęścia pojmowanego jako dobrostan doznawany w trak- 
cie życia ze szczęściem, przez które rozumie się osąd dokonywany o życiu, a także badać wzajemne relacje emocji i uczuć oraz identyfikować warunkujące je zmienne.

\section{Determinanty dobrego samopoczucia}

Co i w jakim zakresie determinuje ocenę życia dokonywaną przez ludzi? Jeśli subiektywny poziom deklarowanego zadowolenia z życia potraktuje się jako zmienną niezależna, to za pomocą metod ekonometrycznych można wyodrębnić kluczowe elementy wpływające na ocenę wyrażaną przez badanych. Frey i Steiner [Frey, Steiner, 2012] wyróżnili sześć grup takich czynników:

- $\quad$ czynniki osobowościowe, w dużej mierze kształtowane genetycznie, takie jak np.: poziom aktywności, otwartości, optymizmu, wrażliwości, przywództwa, lęku, zmienności nastrojów, towarzyskości itp.;

- czynniki społeczno-demograficzne, takie jak: płeć, stan cywilny, wykształcenie, miejsce zamieszkania;

- $\quad$ czynniki ekonomiczne, takie jak np.: poziom dochodów indywidualnych i rodziny jako całości, bezrobocie, inflacja;

- $\quad$ czynniki duchowe, związane z wiarą i religia;

- czynniki indywidualne względne, takie jak np.: zdrowie, warunki lokalowe, warunki pracy, stosunki ze współpracownikami, relacje z otoczeniem;

- czynniki instytucjonalne, czyli m.in.: poziom bezpieczeństwa, dostęp do edukacji, opieki zdrowotnej, informacji, a także stopień uczestnictwa w życiu politycznym i akceptacji poczynań rządu.

Dzięki licznym badaniom, obecnie naukowcy dysponują bogatym zbiorem danych, na podstawie którego starają się dostarczać wiarygodnych informacji na temat znaczenia i siły wpływu poszczególnych zmiennych na odczuwany przez ludzi stopień satysfakcji z życia. Jednak czasami trudno określić kierunek przyczynowości. W wielu przypadkach dostrzega się sprzężenie obustronne: człowiek, który ma satysfakcjonującą pracę, jest bardziej zadowolony, a bardziej zadowolonemu łatwiej jest znaleźć satysfakcjonujące zajęcie; człowiek pozostający w związku małżeńskim lub partnerskim jest spełniony, a spełniona osoba jest bardziej miła dla innych ludzi i łatwiej jej znaleźć partnera; człowiek zdrowy jest radosny, a ponieważ jest radosny, to mniej choruje.

W analizie danych dotyczących subiektywnej oceny jakości życia pomaga znajomość mechanizmów decydujących o poziomie dobrego samopoczucia. W szczególności mowa tu o trzech istotnych procesach psychologicznych, za sprawą których jest łatwiej zrozumieć stan satysfakcji, a mianowicie: przyzwyczajeniu (adaptacji), poziomie aspiracji i porównaniu w obrębie społeczeństwa.

Ludzie posiadają zdolność dostosowywania się do warunków i okoliczności, w jakich się znaleźli. Zgodnie z tym, zmienia się ich subiektywne odczuwanie zadowolenia. Adaptacja powoduje, że człowiek staje się coraz mniej wrażliwy na ciagły lub powtarzający się bodziec i wykazuje na niego słabszą reakcję [Brickman, Campbell, 1971].

Poziom aspiracji sprawia, że ludzie rzadko oceniają swoją sytuację w kategoriach absolutnych, zazwyczaj czynią to w odniesieniu do własnych dążeń i pragnień. Im lepiej 
wygląda ich sytuacja życiowa w stosunku do oczekiwań, tym większe odczuwają zadowolenie z życia [Easterlin, 2001].

Poziom aspiracji rośnie nie tylko w wyniku adaptacji do istniejącej sytuacji, ale także za sprawą względnego porównania własnej sytuacji z sytuacją ludzi w najbliższym otoczeniu. Samopoczucie jest lepsze, gdy wypadamy lepiej niż sąsiedzi. Zatem procesy adaptacyjne i porównawcze powoduja, że aspiracje ludzi nieustannie rosną.

Powyższe mechanizmy psychologiczne należy wziąć pod uwagę przy analizie zależności dobrego samopoczucia od dochodów.

\section{Wpływ dochodów na zadowolenie z życia}

Czy coraz wyższe dochody są determinantem dobrego samopoczucia? Od wielu dziesiątków lat badania prowadzone zarówno przez ekonomistów, jak i psychologów wskazały, że odpowiedź na to pytanie nie jest prosta [Diener, Seligman, 2004; Fischer, Boer, 2011].

Kahneman i Deaton [Kahneman, Deaton, 2010] wykazali, że wyższe dochody powodują wyższy poziom zadowolenia z życia ocenianego jako całość, jednak ich związek z satysfakcją odczuwaną na co dzień jest bardzo nikły. Dowiedli również, że po osiagnięciu określonego poziomu dochodów, dalszy ich wzrost nie wiąże się ze wzrostem dobrego samopoczucia.

Tym, co przyczynia się do tego, że ludzie są smutni i niezadowoleni, jest bieda i ubóstwo. Na poziomie indywidualnym problemy finansowe są silnym predyktorem depresji [Wheaton, 1994], a depresja jest odwrotnie proporcjonalna do odczuwanego szczęścia. Porównanie subiektywnego samopoczucia ludzi w bogatych i ubogich krajach wykazało, że ubodzy są znacznie mniej zadowoleni ze swojego życia niż bogaci [Diener, Oishi, 2000]. Biedni ludzie również znacznie rzadziej doświadczaja pozytywnych emocji i częściej czują się nieszczęśliwi [Bradburn, 1969]. Veenhoven i Hagerty [Veenhoven, Hagerty, 2006] potwierdzili, że wpływ ubóstwa na uczucie nieszczęśliwości jest znacznie bardziej wyraźny niż wpływ bogactwa na poczucie szczęśliwości, zwłaszcza tych osób, które są już stosunkowo zamożne.

Już wcześniej do podobnych wniosków doszli Easterlin [Easterlin, 1995], Oswald [Oswald, 1997] i Myers [Myers, 2000]. Wyniki przeprowadzonych przez nich badań uwierzytelniły to, że wśród osób zamożnych wzrostowi dochodów nie towarzyszy korespondujący wzrost zadowolenia. Dane z General Social Survey w USA pokazały, że choć w latach 1946-1974 dochód na mieszkańca podwoił się, to poziom dobrego samopoczucia pozostał niezmieniony. Podobna sytuacja miała miejsce w Niemczech. W latach 1985-2009 dochód per capita również podwoił się, a średnie zadowolenie z życia nieco obniżyło się (z 7,24 do 7,11 na dziesięciostopniowej skali). Z kolei, w Japonii w latach 1958-1991 dochód per capita wzrósł aż sześciokrotnie, a zadowolenie mieszkańców tego kraju nie uległo znaczącym zmianom [Frey, Stutzer, 2002, s. 9-77].

Niezdolność dochodów do zwiększania satysfakcji osób dobrze sytuowanych oraz wyraźny związek między biedą a odczuwaniem nieszczęścia są zgodne z teorią livability [Veenhoven, 1995]. Teoria ta głosi, iż wraz ze wzrostem dochodów zwiększa się poziom 
dobrego samopoczucia, ale tylko wtedy, gdy dochody te zaspokajaja podstawowe potrzeby człowieka. Gdy potrzeby te nie sa już odczuwalne, wzrost majętności nie wpływa zauważalnie na zmianę poziomu zadowolenia. Na przykład korelacja pomiędzy dochodami a zadowoleniem jest ponad dwa razy silniejsza w slumsach Kalkuty niż w Stanach Zjednoczonych [Biswas-Diener, Diener, 2001]. Frey i Stutzer [Frey, Stutzer, 2002] oraz Helliwell [Helliwel, 2003] zauważyli podczas badań w wielu krajach, że gdy dochód na mieszkańca przekroczy pewną kwotę, to nie obserwuje się dalszego wzrostu poziomu satysfakcji. Tłumaczy to wspomniana wcześniej psychologiczna zasada adaptacji. Wraz z poprawą sytuacji rosną pragnienia i oczekiwania ludzi. Szybko przyzwyczajają się oni do wyższego poziomu życia i ich wymagania dalej rosna.

Gdy jednak aspiracje ludzi rosną szybciej niż ich dochody, może to prowadzić do frustracji [Graham, Pettinato, 2002]. Bogactwo pozwala więc ludziom na przeżywanie pozytywnych doświadczeń, lecz może również nieść ze sobą problemy, które powoduja niezadowolenie. Na przykład zwiększone pragnienia w sferze materialnej, które wynikają z dobrobytu, często moga przyczyniać się do niższej samooceny, skutkować: większym narcyzmem, mniejszą empatią, niższą wewnętrzną motywacją i częstszymi konfliktami interpersonalnymi [Kasser $i$ in. 2004].

W wielu krajach rozwiniętych (np. w: Kanadzie, Szwecji, Niemczech, Nowej Zelandii, USA) mimo zwiększania dochodu narodowego per capita, rośnie liczba ludzi cierpiących na depresje [Lane, 2000]. Niemal we wszystkich krajach Zachodu, poczawsszy od lat siedemdziesiątych, jednocześnie rośnie liczba samobójstw [Oswald, 1997]. Jungeilges i Kirchgaessner [Jungeilges, Kirchgaessner, 2002] wykazali znaczna pozytywną korelację między dochodem per capita a liczbą samobójstw przypadających na 100 tys. mieszkańców w USA oraz w reprezentatywnej grupie krajów europejskich. Wyniki te potwierdziły to, iż po zaspokojeniu podstawowych potrzeb, na poziom dobrego samopoczucia w znacznie większym stopniu niż bogactwo oddziałują inne czynniki istotne dla człowieka.

\section{Praca a poziom zadowolenia}

Di Tella, MacCulloch i Oswald [Di Tella, MacCulloch, Oswald, 2001] przedstawili rezultaty obszernych badań dotyczących wpływu bezrobocia na poziom dobrego samopoczucia, przeprowadzonych w 12 krajach europejskich. Analizy prowadzono na podstawie danych za lata 1975-1991. Wynika z nich, że poziom zadowolenia z życia deklarowany przez osoby bezrobotne jest znacznie niższy niż u osób pracujących, przy pozostałych determinantach zbliżonych w obu grupach. Podobne wyniki uzyskano w wielu innych badaniach, w rozmaitych krajach i różnych okresach. Pisali o nich Clark i Oswald [Clark, Oswald, 1994] - Wielka Brytania, Korpi [Korpi, 1997] - Szwecja, Björklund i Eriksson [Björklund, Eriksson, 1998] - kraje skandynawskie, Ravallion i Lokshin [Ravallion, Lokshin, 2001] - Rosja, Blanchflower i Oswald [Blanchflower, Oswald, 2004] - Wielka Brytania i Stany Zjednoczone. Clark i Oswald [Clark, Oswald, 1994], podsumowując rezultaty badań, podkreślili, iż bezrobocie prowadzi do tak dużej depresji, jakiej nie powodują inne, szczególnie niesprzyjające wydarzenia, jak np. sepa- 
racja czy rozwód. Badania ujawniły także inne zależności. Otóż okazuje się, że bezrobocie ma bardziej negatywny wpływ na spadek poziomu satysfakcji z życia u osób lepiej wykształconych. Ponadto, utratę pracy dużo gorzej znoszą mężczyźni niż kobiety. Zaobserwowano również różnicę ze względu na wiek. W sytuacji braku zatrudnienia lepiej radzą sobie osoby młode i starsze niż osoby w średnim wieku produkcyjnym. Badania przeprowadzone w Niemczech [Gerlach, Stephan, 1996] wykazały wręcz, że utrata pracy nie przyczyniła się do spadku zadowolenia z życia u kobiet powyżej 50. roku życia.

Bezrobocie to nie tylko utrata dochodów. To równocześnie ogromne straty natury psychologicznej i społecznej, jakie dotykają osobę tracącą pracę. Wiążą się one ze spadkiem samooceny, poczuciem braku przydatności i utraty kontroli nad swoim życiem. Następuje ograniczanie kontaktów międzyludzkich. W przypadku osób mocno zaangażowanych w swoją pracę pojawiają się problemy ze zdrowiem i rośnie zagrożenie popadnięcia w nałóg. Często jest to zarazem bardzo trudny okres zmiany priorytetów i ponownego poszukiwania sensu życia. Wysokie koszty ponoszą przede wszystkim osoby zwalniane po raz pierwszy. Osoby, które traca pracę po raz kolejny, cierpia mniej, gdyż są niejako przyzwyczajone do bezrobocia. Zdaniem Clarka, Georgellisa i Sanfeya [Clark, Georgellis, Sanfey, 2001], fakt ten może w pewnej mierze tłumaczyć zjawisko bezrobocia długotrwałego.

Zatrudnienie to nie tylko możliwości uzyskiwania dochodów. Praca daje spełnienie, satysfakcję, uczy i rozwija. W pracy ważna jest atmosfera i życzliwość współpracowników. Im praca ciekawsza, zgodna z zainteresowaniami człowieka, tym bardziej uszczęśliwia. W literaturze wśród głównych determinant zadowolenia z pracy są wymieniane: relacje między pracownikami, różnorodność zadań i bezpieczeństwo pracy [Cornelißen, 2009].

Jednocześnie okazuje się, że istotna jest forma zatrudnienia. Zauważono bowiem [Binder, Coad, 2013], że osoby, które zmieniają pracę z umowy o pracę na samozatrudnienie, doświadczaja znacznego wzrostu poziomu satysfakcji z życia i efekt ten rośnie jeszcze w ciagu dwóch lat od zmiany formy zatrudnienia. Z kolei, gdy osoba bezrobotna podejmuje pracę, to jej poziom zadowolenia rośnie tak samo, niezależnie od formy rozpoczynanej pracy, tj. czy jest to praca najemna, czy praca na własny rachunek.

Ostrożnie należy traktować stwierdzenie, że awans zawsze podnosi poziom ukontentowania u pracownika. Z jednej strony awans zazwyczaj łączy się z podwyżką, większymi uprawnieniami i przywilejami, z drugiej to również często dłuższy czas pracy, większa odpowiedzialność i trudniejsze zadania, a co za tym idzie, większy stres. Johnston i Lee [Johnston, Lee, 2013] przeprowadzili badania, na podstawie których można stwierdzić, że efekt wzrostu zadowolenia utrzymuje się jedynie przez pewien czas po awansie, później pozytywne emocje nikna. Około dwa lata po awansie jest widoczny jego negatywny wpływ na zdrowie psychiczne pracownika, który niejednokrotnie objawia się pojawianiem stanów lękowych.

Natomiast, jak wygląda związek między czasem przeznaczanym na pracę a poziomem dobrego samopoczucia? Z badań, o których pisali Van der Meer i Wielers [van de Meer, Wielers, 2013], wynika, że poziom zadowolenia, jaki przynosi praca na część etatu, jest podobny do poziomu satysfakcji odczuwanej w związku z pracą na pełen etat, ale 
pod warunkiem że pracownik samodzielnie decyduje o wyborze godzin pracy. Owa elastyczność pracy rekompensuje mu utracone zarobki z tytułu pracy na niepełny etat. W momencie, gdy pracownik traci możliwość rozstrzygania o godzinach wykonywania pracy, osiagany przez niego poziom ukontentowania będzie niższy.

Booth i van Ours [Booth, van Ours, 2009] dowiedli, że praca w niepełnym wymiarze często jest praca niedającą szansy na karierę, tym samym sprawiając mniej satysfakcji (mimo że, jak zauważyli Johnston i Lee [Johnston, Lee, 2013], awans nie podnosi poziomu zadowolenia, tak jak ogólnie się wydaje). Tezę tę potwierdziły również rezultaty wcześniejszych badań [Hakim, 1997; Gallie i in. 1998], zgodnie z którymi praca pełnoetatowa stwarza znacznie więcej możliwości rozwoju zawodowego oraz daje szerszy dostęp do szkoleń i edukacji.

Z drugiej strony praca na część etatu sprzyja równowadze życia zawodowego i osobistego (Work-Life Balance). Równowaga ta wpływa na poczucie własnej wartości w kilku obszarach życia. Praca na dosłownie kilka godzin powoduje, iż pracownik nie myśli o sobie w kategorii bezrobotnego. Jak udowodnili psychologowie [Diener i in. 1999], w wielu przypadkach sama możliwość wykonania pracy jest swoistego rodzaju niematerialną nagrodą dającą satysfakcję. Osoby zatrudnione na część etatu częściej niż pełnoetatowcy wskazuja także na znaczenie relacji ze wspólpracownikami oraz kontakty towarzyskie, które stały się możliwe dzięki pracy.

Ważnym elementem różnicującym poziom dobrego samopoczucia osiagany przez pracowników pełnoetatowych i pracujących na część etatu jest płeć. Z badań przeprowadzonych w Australii [Booth, van Ours, 2009], jak również w Wielkiej Brytanii i w Niemczech [Gash i in. 2009] wynika, że kobiety są bardziej zadowolone z pracy na część etatu, a mężczyźni z pracy na cały etat. Sousa-Poza i Sousa-Poza [2000a; 2000b], analizując wyniki Międzynarodowego Programu Badań Społecznych (International Social Survey Programme - ISSP), jedynie w przypadku kobiet dostrzegli negatywny wpływ wzrostu liczby godzin pracy na satysfakcję z pracy.

Jednocześnie istnieją nieliczne badania, w których udowodniono, że zatrudnieni w niepełnym wymiarze czasu są bardziej zadowoleni niż osoby pracujące na pełen etat [Ehrenberg, Smith, 1997; Clark, 1997; Booth, van Ours, 2008].

Jakkolwiek zależność między poziomem satysfakcji a bezrobociem wiążąca się z badaniami jest oczywista, to naukowcy nie do końca zgadzają się z kierunkiem tej relacji. Co jest przyczyna, a co skutkiem? Czy bezrobocie prowadzi do braku satysfakcji z życia, czy też jest odwrotnie, tzn. osoby nieszczęśliwe nie wykonują swojej pracy dobrze i są zwalniane? Pytanie o kierunek przyczynowości było podstawą wielu analiz danych długookresowych zbieranych przed i po utracie pracy przez respondentów. Wyniki badań w Niemczech [Winkelmann, Winkelmann, 1998] i Australii [Marks, Fleming, 1999] potwierdziły, prawdziwość tezy, że ludzie nieszczęśliwi nie odnajdują się na rynku pracy, ale znacznie bardziej wyraźna jest zależność, zgodnie z którą to bezrobocie prowadzi do braku satysfakcji z życia. Na uwagę zasługuje jeszcze jeden wniosek: ogólnie osoby szczęśliwe są bardziej optymistycznie nastawione do życia (w tym zawodowego), co równocześnie czyni je mniej niezadowolonymi w momencie, gdy zostaną zwolnione.

Bezrobocie jako zjawisko społeczne przyczynia się zarazem do spadku poziomu satysfakcji wśród osób pracujących. Żyją oni w większym strachu, poczuciu niepew- 
ności i zagrożenia, że ich także może to spotkać. Odczuwają napięcia społeczne (strajki, protesty, wzrost patologii i przestępczości) oraz reperkusje ekonomiczne związane $z$ bezrobociem (pogorszenie stanu budżetu państwa przez zmniejszenie wpływów $z$ podatków i jednoczesne zwiększanie wydatków na zasiłki i inne formy pomocy społecznej).

W ujęciu indywidualnym, w przypadku bezrobocia również oddziałuje mechanizm porównania. Ludzie tracący pracę czują się mniej zrozpaczeni, gdy nie są w tym osamotnieni. Jeśli bezrobocie dotyka wielu osób, łatwiej im to znieść. Także pewien stygmatyzm i dezaprobata stają się być mniej nasilone, jeżeli urata pracy dotyczy dużej grupy osób w tym samym czasie. Bezrobotni zachowują lepszą samoocenę, a wytłumaczenie utraty pracy łatwiej im znaleźć w kłopotach gospodarczych kraju niż we własnych słabościach.

Jak silnych emocji doświadczają ludzie tracący pracę zależy zarazem od norm społecznych związanych z podejściem do pracy w danym kraju. Bezrobocie szczególne piętno wyciska na społeczeństwach, w których praca definiuje pozycję w życiu.

Maennig i Wilhelm [Maennig, Wilhelm, 2012] zwrócili uwagę na wyraźną asymetryczność efektów wpływających na stopień satysfakcji z życia przy zmianach statusu $z$ osoby pracującej na bezrobotną i odwrotnie. Mianowicie, badacze ci dowiedli, że wejście na rynek pracy przynosi korzyści niematerialne, które w większym stopniu wpływają na poziom zadowolenia niż negatywne oddziaływanie dotyczące utraty pracy. Można to potraktować jako kolejny dowód na siłę i znaczenie, jakie dla współczesnego człowieka ma praca zawodowa.

\section{Podsumowanie}

Analizując związek poziomu satysfakcji i dochodów, można stwierdzić, iż pieniądze przyczyniają się do dobrego samopoczucia, jednak po tym, gdy zaspokoja już podstawowe potrzeby, bardzo niewiele daja tego zadowolenia. Stąd związek między wzrostem PKB a odczuwanymi przez ludzi stanami intensywnej radości głównie jest widoczny w przypadku krajów najuboższych.

Istotne są mechanizmy psychologiczne, jakie rządzą naturą ludzką i ujawniają się w procesie bogacenia. Ludzie dość szybko przyzwyczajają się do nowej, lepszej sytuacji. Wobec tego ich aspiracje i pragnienia rosna, co sprawia, iż poziom zadowolenia nie rośnie wraz ze wzrostem dochodów. Jeśli człowiek aspiruje do posiadania dóbr pozycjonalnych, to $\mathrm{w}$ większości przypadków pragnienia te nie zostaną zrealizowane, co może powodować frustrację i obniżenie poziomu satysfakcji. Ponadto, ludzie oceniając swój dobrostan, biorą pod uwagę nie tyle absolutny poziom bogactwa, ale jego poziom względny, w relacji do tego, co posiadają inni. Zatem, jeżeli nasz dochód rośnie, lecz dochód innych rośnie szybciej, to również powstaje tendencja w kierunku obniżenia poziomu zadowolenia.

Co więcej, pieniądze potrafią skutecznie odwrócić uwagę człowieka od pielęgnowania rzeczy niematerialnych, które w prosty sposób dostarczają wiele radości, takich 
jak relacje międzyludzkie czy aktywność społeczna, a w końcowym rozrachunku moga negatywnie wpłynąć na poziom zadowolenia.

Drugi ważny czynnik ekonomiczny, którego korelacja z poziomem zadowolenia jest bardzo wyraźna, to praca. Człowiek posiadający zatrudnienie zyskuje nie tylko dochód, ale również bardzo istotne wartości pozafinansowe, a mianowicie: wyższą samoocenę, prestiż społeczny, możliwości rozwoju i samorealizacji. Mimo braku jednoznacznej odpowiedzi na pytanie, czy awans powoduje wzrost poziomu satysfakcji, ludzie pną się po kolejnych szczeblach kariery, kierowani coraz wyższymi aspiracjami.

Na podstawie badań trudno jednoznacznie określić relację między czasem pracy a poziomem zadowolenia z życia, jednak zdecydowanie można skonstatować, iż istotnym czynnikiem różnicującym jest płeć. Kobiety mają więcej satysfakcji z życia, gdy wykonuja pracę w niepełnym wymiarze godzin.

\section{Literatura}

Ahuvia A.C., Friedman D., 1998, Income, Consumption, and Subjective Well-Being: Toward a Composite Macromarketing Model, „Journal of Macromarketing”, no. 18.

Binder M., Coad A., 2013, Life Satisfaction and Self-Employment: a Matching Approach, „Small Business Economics”, no. 40(4).

Biswas-Diener R., Diener E., 2001, Making the best of a bad situation: Satisfaction in the slums of Calcutta, „Social Indicators Research”, no. 55.

Björklund A., Eriksson T., 1998, Unemployment and mental health: evidence from research in the Nordic countries, „Scandinavian Journal of Social Welfare”, no. 7(3).

Blanchflower D., Oswald A., 2004, Well-being over time in Britain and the USA, „Journal of Public Economics", no. 88.

Booth A. L., van Ours J. C., 2008, Job satisfaction and family happiness: the part-time work puгzle, ,The Economic Journal”, no. 118.

Booth A. L., van Ours J. C., 2009, Hours of work and gender identity: does part-time work make the family happier?, „Economica”, no. 76.

Bradburn N.M., 1969, The structure of psychological well-being, Aldine, Chicago.

Brickman P., Campbell D. T., 1971, Hedonic relativism and planning the food society, [in:] Adaptation-level theory, M. H. Appley (ed.), Academic Press, New York.

Carr A., 2009, Psychologia posytymna. Nauka o szczesscin i ludzkich sitach, Wydawnictwo Zysk i S-ka, Poznań.

Clark A. E., 1997, Job satisfaction and gender: why are women so happy at work?, „Labour Economics", no. 4.

Clark A., Georgellis Y., Sanfey P., 2001, Scarring: The psychological impact of past unemployment, „Economica”, no. 68(270).

Clark A., Oswald A., 1994, Unhappiness and Unemployment, „The Economic Journal”, no. 104(424).

Cornelißen T., 2009, The Interaction of Job Satisfaction, Job Search, and Job Changes. An Empirical Investigation with German Panel Data, „Journal of Happiness Studies", no. 10(3). 
Di Tella R., MacCulloch R., Oswald A., 2001, Preferences over Inflation and Unemployment: Evidence from Surveys of Happiness, „The American Economic Review”, no. 91(1).

Diener E., Oishi S., 2000, Money and happiness: Income and subjective well-being across nations, [in:] Subjective Well-being across Cultures, E. Diener, E.M. Suh (eds.), MIT Press, Cambridge, MA.

Diener E., Seligman M.E.P., 2004, Beyond Money: Toward The Economy of Well-being, „Psychological Science in the Public Interest”, no. 5.

Diener E., Suh E. M., Lucas R. E., Smith H. L., 1999, Subjective well-being: three decades of progress, „Psychological Bulletin”, no. 125.

Easterlin R. A., 1995, Will raising the incomes of all increase the happiness of all?, "Journal of Economic Behavior and Organization", no. 27.

Easterlin R. A., 2001, Income and happiness: towards a unified theory, "The Economic Journal", no. 111(473).

Ehrenberg R. G., Smith R. S., 1997, Modern Labor Economics: Theory and Public Policy, Addison-Wesley, Reading, MA.

Eurostat, 2015, Quality of life in Europe - facts and views, http://ec.europa.eu/eurostat/ statistics-explained/index.php/Quality_of_life_in_Europe_-_facts_and_views (data wejścia: 28.08.2015).

Fischer R., Boer D., 2011, What is more important for national well-being: money or autonomy? A meta-analysis of well-being, burnout and anxiety across 63 societies, ,Journal of Personality and Social Psychology", no. 101(1).

Frey B. S., Steiner L., 2012, Glücksforschung: Eine empirische Analyse, „AStA Wirtschaftsund Sozialstatistisches Archiv“, no. 6.

Frey B. S., Stutzer A., 2002, Happiness and Economics, How the Economy and Institutions Affect Well-Being, Princeton University Press, Princeton.

Gallie D., White M., Cheng Y., Tomlinson M., 1998, Restructuring the Employment Relationship, Oxford University Press, Oxford.

Gash V., Mertens A., Romeu-Gordo, L., 2009, Women Between Part-Time and Full-Time Work: The Influence of Changing Hours of Work on Happiness and Life-Satisfaction, The University of Manchester, Manchester.

Gerlach K., Stephan G., 1996, A paper on unhappiness and unemployment in Germany, „Economics Letters”, no. 52(3).

Graham C., Pettinato S., 2002, Frustrated achievers: Winners, losers and subjective well-being in new market economies, ,Journal of Development Studies”, no. 38.

Hakim C., 1997, A sociological perspective on part-time work, [in:] Between Equalization and Marginalization: Women Working Part-time in Europe and the United States of America, H. Blossfeld, C. Hakim (eds.), Oxford University Press, Oxford.

Handbook on the Economics of Happiness, 2007, L. Bruni, P.L. Porta (eds.), Edward Elgar Publishing, Cheltenham UK, Northampton, MA, USA.

Helliwell J. F., 2003, How's life? Combining individual and national variables to explain subjective well-being, „Economic Modelling”, no. 20.

Johnston D.W., Lee W.S., 2013, Extra Status and Extra Stress: Are Promotions Good for Us?, „Industrial and Labor Relations Review”, no. 66(1). 
Jungeilges J., Kirchgaessner G., 2002, Economic Welfare, Civil Liberty, and Suicide, „Journal of Socio-economics", no. 31.

Kahneman D., 2012, Pułapki myślenia. O myśleniu szybkim i wolnym, Wydawnictwo Media Rodzina, Poznań.

Kahneman D., Deaton A., 2010, High income improves evaluation of life but not emotional well-being, „Proceedings of the National Academy of Sciences of the United States of America", no. 107.

Kahneman D., Krueger A.B., 2006, Developments in the measurement of subjective wellbeing, ,Journal of Economic Perspectives”, no. 20(1).

Kasser T., Ryan R.M., Couchman C.E., Sheldon K.M., 2004, Materialistic values: Their causes and consequences, [in:] Psychology and consumer culture: The struggle for a good life in a materialistic world, T. Kasser, A.D. Kanner (eds.), American Psychological Association, Washington.

Korpi T., 1997, Is utility related to employment status? Employment, unemployment, labor market policies and subjective well-being among Swedish youth, „Labour Economics”, no. 4(2).

Lane R.E., 2000, The loss of happiness in the market democracies, Yale University Press, New Haven, London.

Maennig W., Wilhelm M., 2012, Becoming (un)employed and life satisfaction: asymmetric effects and potential omitted variable bias in empirical happiness studies, „Applied Economics Letters", no. 19.

Marks G., Fleming N., 1999, Influences and consequences of well-being among Australian young people: 1980-1995, „Social Indiators Research”, no. 46.

Myers D., 2000, American paradox: Spiritual hunger in an age of plenty, Yale University Press, New Haven.

Oswald A.J., 1997, Happiness and economic performance, ,'The Economic Journal”, no. 107. Psychologia pozytywna w praktyce, 2007, P.A. Linley, P.A. Joseph S. (eds.), Wydawnictwo Naukowe PWN, Warszawa.

Ravallion M., Lokshin M., 2001, Identifying Welfare Effects from Subjective Questions, „Economica”, no. 68(271).

Sousa-Poza A., Sousa-Poza A. A., 2000a, Taking another look at the gender/job-satisfaction paradox, „Kyklos”, no. 53.

Sousa-Poza A., Sousa-Poza A. A., 2000b, Well-being at work: a cross-national analysis of the levels and determinants of job satisfaction, „Journal of Socio-Economics”, no. 29.

Tatarkiewicz W., 2003, O szçeściu, Wydawnictwo Naukowe PWN, Warszawa.

Van der Meer P., Wielers R., 2013, What makes workers happy?, „Applied Economics”, no. 45.

Veenhoven R., 1995, The cross-national pattern of happiness: Test of predictions implied in three theories of happiness, „Social Indicators Research”, no. 34.

Veenhoven R., Hagerty M., 2006, Rising happiness in nations 1946- 2004: A reply to Easterlin, „Social Indicators Research”, no. 79.

Well-being: the foundations of hedonic psychology, 1999, Kahneman D., Diener E., Schwarz N. (Hrsg), Russell Sage Foundation, New York. 
Wheaton B., 1994, Sampling the stress universe, [in:] Stress and Mental Health, W. R. Avison, I. H. Gotlib (eds.), Plenum Press, New York.

Winkelmann L., Winkelmann R., 1998, Why are the Unemployed So Unhappy? Evidence from Panel Data, „Economica”, no. 65(257). 